\title{
Liquid particle composition and heterogeneous reactions in a mountain wave Polar Stratospheric Cloud
}

\author{
D. Lowe ${ }^{1}$, A. R. MacKenzie ${ }^{1}$, H. Schlager ${ }^{2}$, C. Voigt $^{2}$, A. Dörnbrack ${ }^{2}$, M. J. Mahoney ${ }^{3}$, and F. Cairo ${ }^{4}$ \\ ${ }^{1}$ Environmental Science Dept., Lancaster University, Lancaster, UK \\ ${ }^{2}$ Institute for Atmospheric Physics, DLR, Oberpfaffenhofen, Germany \\ ${ }^{3}$ Jet Propulsion Laboratory, California Institute of Technology, Pasadena, California, USA \\ ${ }^{4}$ Institute of Atmospheric Sciences and Climate of the National Research Council (CNR-ISAC), Rome, Italy \\ Received: 25 April 2005 - Published in Atmos. Chem. Phys. Discuss.: 4 October 2005 \\ Revised: 9 May 2006 - Accepted: 16 August 2006 - Published: 6 September 2006
}

\begin{abstract}
Mountain wave polar stratospheric clouds (PSCs) were detected on 8 February 2003 above the Scandinavian Mountains by in-situ instruments onboard the M55 Geophysica aircraft. PSC particle composition, backscatter and chlorine activation for this case are studied with a recently developed non-equilibrium microphysical box model for liquid aerosol. Results from the microphysical model, run on quasilagrangian trajectories, show that the PSC observed was composed of supercooled ternary $\left(\mathrm{H}_{2} \mathrm{O} / \mathrm{HNO}_{3} / \mathrm{H}_{2} \mathrm{SO}_{4}\right)$ solution (STS) particles, which are out of equilibrium with the gas phase. The measured condensed nitric acid and aerosol backscatter of the PSC can well be simulated with the model. Up to $0.15 \mathrm{ppbv} \mathrm{Cl}_{2}$ can be released by the PSC within $2 \mathrm{~h}$, showing the propensity of these small-scale clouds for chlorine activation. Equilibrium calculations - of the sort commonly used in large scale chemistry transport models - overestimate the measured condensed nitrate by up to a factor of 3 , and overestimates chlorine activation by $10 \%$, in this mountain wave cloud.
\end{abstract}

\section{Introduction}

Polar stratospheric clouds (PSCs) have long been recognised to play an important role in the destruction of stratospheric ozone via chlorine activation, dehydration and denitrification (for a detailed review and discussion see, for example, WMO, 2003, and references within). PSCs are, however, composed of a range of different particles, both solid and liquid, the combination of which governs their environmental influence. Below the frost point solid type II particles can exist, composed of water ice. Up to several degrees

Correspondence to: A. R. MacKenzie

(r.mackenzie@lancaster.ac.uk) above the frost point $\mathrm{HNO}_{3}$-rich type I particles can form. These can consist of solid nitric acid trihydrate (NAT) (Hanson and Mauersberger, 1988) as observed by balloon-borne in-situ mass spectrometry (Voigt et al., 2000a) - or possibly dihydrate (NAD) (Worsnop et al., 1993). Additionally, supercooled ternary solution (STS) droplets (Molina et al., 1993; Zhang et al., 1993; Carslaw et al., 1994) form via the condensation of $\mathrm{HNO}_{3}$ and $\mathrm{H}_{2} \mathrm{O}$ onto the background binary $\mathrm{H}_{2} \mathrm{SO}_{4} / \mathrm{H}_{2} \mathrm{O}$ aerosol.

Models of liquid STS PSCs (Carslaw et al., 1994; Tabazadeh et al., 1994a) were initially developed to match the observations of total particle volume reported by Dye and co-workers (Dye et al., 1992). The STS models also explained the classification of lidar PSC observations into depolarising (type 1a) and non-depolarising (type 1b) clouds (Browell et al., 1990; Toon et al., 1990). Further modeldata comparisons of PSC occurrence ensued (e.g., Tabazadeh et al., 1994b, 1996; Toon et al., 1995; Larsen et al., 1997), including quasi-Lagrangian remote sensing of PSCs (Carslaw et al., 1998; Wirth et al., 1999), which began to tease out the time- and temperature-dependence of transitions between PSC types.

The transition from a sulphuric- to nitric-acid-dominated solution occurs over a relatively small temperature interval of $\sim 2 \mathrm{~K}$ about $3-5 \mathrm{~K}$ above the ice frostpoint. The speed at which this change in composition occurs is controlled by the condensation rates of the individual components; the condensation rates are themselves determined by the particle size and partial pressure of the component in the gas phase. Thus, while the $\mathrm{H}_{2} \mathrm{O}$-content of the condensed-phase can reach equilibrium with the atmosphere within seconds, the condensed-phase $\mathrm{HNO}_{3}$-content can take from several minutes for smaller particles $(\approx 0.1 \mu \mathrm{m})$ to several hours for the largest particles $(\approx 2 \mu \mathrm{m})$. The limited uptake rate of $\mathrm{HNO}_{3}$

Published by Copernicus GmbH on behalf of the European Geosciences Union. 


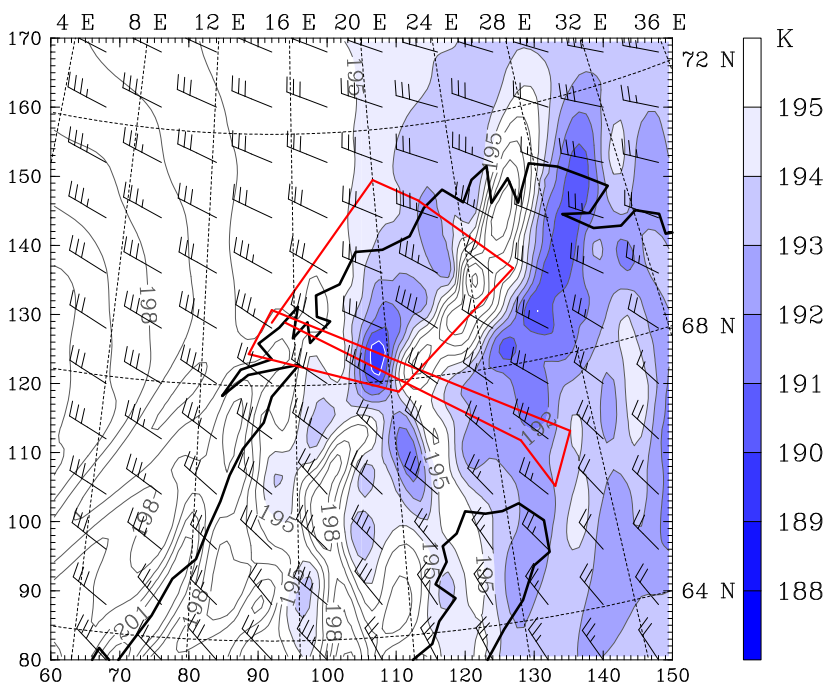

Fig. 1. Hindcast of air temperature at 50 mbar for 18:00 UTC, 8 February 2003 from the MM5 mesoscale model. The red line indicates the flight path of the Geophysica.

means that rapid temperature fluctuations, such as those occurring within mountain lee waves, can lead to droplets with highly non-equilibrium compositions (Meilinger et al., 1995; Lowe et al., 2003).

The heterogeneous chemical processes involved in chlorine activation have been extensively studied in laboratory work (see, for example, Sander et al., 2003, and references within. A gap in the published parameterisations is noted in Sect. 4.1, however.). Whilst the majority of the chemical constituents involved in these processes have been measured on a range of scales, from in-situ to global, modelling studies of chlorine activation have tended to focus on global/regional effects, originally incorporating the heterogeneous processes as empirical effects, which are compared with large-scale rather than in-situ observations (e.g. Kühl et al., 2004). Recent work has incorporated microphysical PSC schemes into regional-scale chemical models (Drdla and Schoeberl, 2003; Mann et al., 2003). Microphysical models have previously been used to model chlorine activation, initially considering just background aerosols and NAT PSCs (Jones et al., 1990; Lutman et al., 1994), but later considering more complicated populations of particles (Drdla, 1996; Sessler et al., 1996; Carslaw et al., 1998). However, quasi-Lagrangian studies of PSC formation and chlorine activation have not been carried out, because measurements of PSCs have been remote rather than in-situ (Carslaw et al., 1998; Wirth et al., 1999), or because measurements of chlorine activation have not been quasi-Lagrangian (Kawa et al., 1997).

Until recently the chemical compositions of PSC particles have had to be inferred from gas-phase compositions and the polarisation of lidar signals or from size distributions measured by optical particle counters; however the develop- ment of balloon-borne mass spectrometers (Schreiner et al., 1999), and aeroplane-borne chemiluminescence instruments (Northway et al., 2002), designed to measure the $\mathrm{NO}_{\mathrm{y}}$ content of the particle phase, mean that the chemical composition of PSCs can now be measured directly.

These balloon-borne in-situ measurements positively identified NAT (Voigt et al., 2000a) and STS (Voigt et al., 2000b) in mountain wave PSCs. Recently such measurements have also been used to confirm the presence on $\mathrm{HCl}$ in STS particles (Weisser et al., 2006). Because the balloons carrying these instruments follow quasi-lagrangian flight-paths, the measurements are highly suited to the creation of lagrangian trajectories for 0-D models (Voigt et al., 2003). In addition, in-situ measurements of the $\mathrm{NO}_{\mathrm{y}}$ content of the particle and gas phases allowed the identification of very low number densities of relatively large ( $5 \mu \mathrm{m}$ radius) NAT particles (so-called "NAT-rocks") during the SOLVE/THESEO 2000 campaign (Fahey et al., 2001).

The microphysical studies mentioned above concentrated purely on particle compositions, with no consideration of the heterogeneous reactions occurring on these particles. Studies of these reactions which use a microphysical box-model (e.g. Carslaw et al., 1998) have not been able to make comparisons of the model output with in-situ measurements of the changes in the mixing ratios of chlorine compounds passing through the PSC event. One of the aims of the VINTERSOL-EuPLEx campaign is to study halogen activation within PSCs. To this end the M-55 Geophysica aircraft was fitted with instruments to make in-situ measurements of particle composition and a number of chlorine species. Care was taken to fly the Geophysica parallel to the wind-direction close to, or within, PSCs in order to allow quasi-lagrangian studies of the evolution of these PSC properties to be made. Below we will examine one such flight from EuPLEx, comparing the particle compositions with those calculated by our microphysical model (Lowe et al., 2003), and with an equilibrium composition STS model such as commonly used in chemistrytransport models (e.g. Sessler et al., 1996). We shall examine the differences in $\mathrm{Cl}_{2}$ production between the two models. Direct comparison with $\mathrm{ClO}_{\mathrm{x}}$ observations are not possible because of the high solar zenith angles during the flight (see below).

\section{Meteorological forecast and flight plan}

The meteorological conditions above northern Scandinavia on 8 February 2003 were favourable for the excitation and vertical propagation of mountain waves. These waves formed mesoscale stratospheric temperature anomalies which extended from directly above to around $200 \mathrm{~km}$ downstream of the mountain range (Fig. 1). The hindcast simulation from the MM5 mesoscale model indicates the presence of two nearly parallel regions of low temperatures with a peak-to-peak amplitude of about $12 \mathrm{~K}$, whereas the 


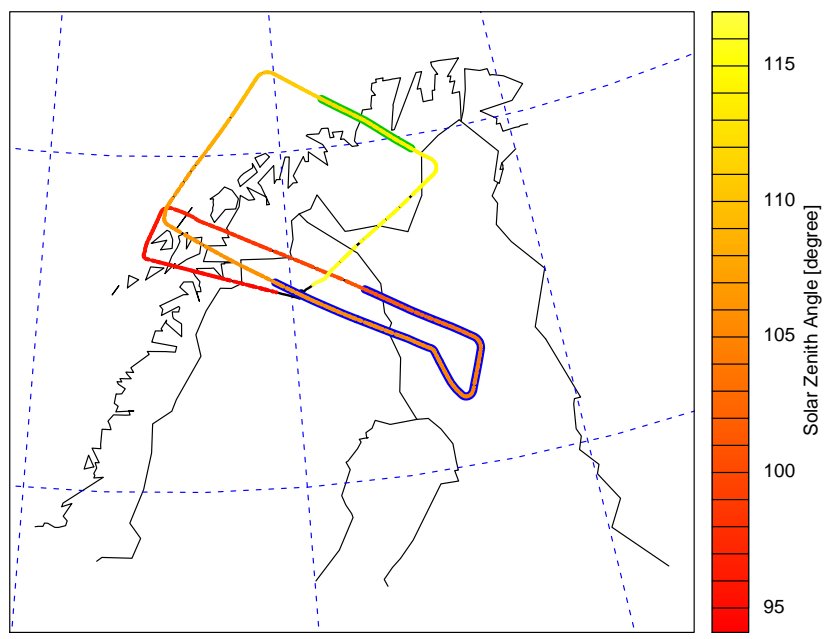

Fig. 2. The changes in solar zenith angle during the flight of the Geophysica aircraft on 8 February 2003. The green and blue sections roughly indicate where the aircraft passed through PSCs.

cooling with respect to the upstream conditions amounts to about $6 \mathrm{~K}$.

Tropospheric excitation conditions varied on 8 February 2003, so that the stratospheric mountain wave event only lasted for about $6 \mathrm{~h}$. Therefore, and in contrast to former documented events (Dörnbrack et al., 1999, 2002), the cooling within the waves was limited to $6 \mathrm{~K}$.

Based on the MM5 forecasts (Dörnbrack et al., 1998) a flight plan was drawn up for the Geophysica to include several passes through these mountain waves parallel to the wind direction; on the day the flight path was fine-tuned using lidar observations from the Falcon aircraft. The Geophysica passed through a number of PSCs, the positions of which are indicated in Fig. 2.

\section{Measurements}

The Geophysica aircraft carries a wide-range of instruments, from lidar through to whole-air samplers (Stefanutti et al., 2004); in this study, however, we shall primarily use data from the SIOUX instrument (Schmitt, 2003; Voigt et al., 2005) - a chemiluminescence detector similar to that used by Northway et al. (2002) on the ER-2 aircraft. We will also use temperature data from the JPL MTP (Microwave Temperature Profiler) instrument (Denning et al., 1989); aerosol backscatter data from the MAS instrument (Adriani et al., 1999); total $\mathrm{H}_{2} \mathrm{O}$ mixing ratios from the FISH (Fast InSitu Hygrometer (Zöger et al., 1999); $\mathrm{N}_{2} \mathrm{O}$ mixing ratios from the HAGAR instrument (Stefanutti et al., 2004); and $\mathrm{ClO}, \mathrm{ClOOCl}$ and $\mathrm{ClONO}_{2}$ mixing ratios from the HALOX (HALogen OXide monitor) instrument (Brune et al., 1989; von Hobe et al., 2005). Although the Geophysica carried a FSSP aerosol spectrometer to measure the aerosol size dis-

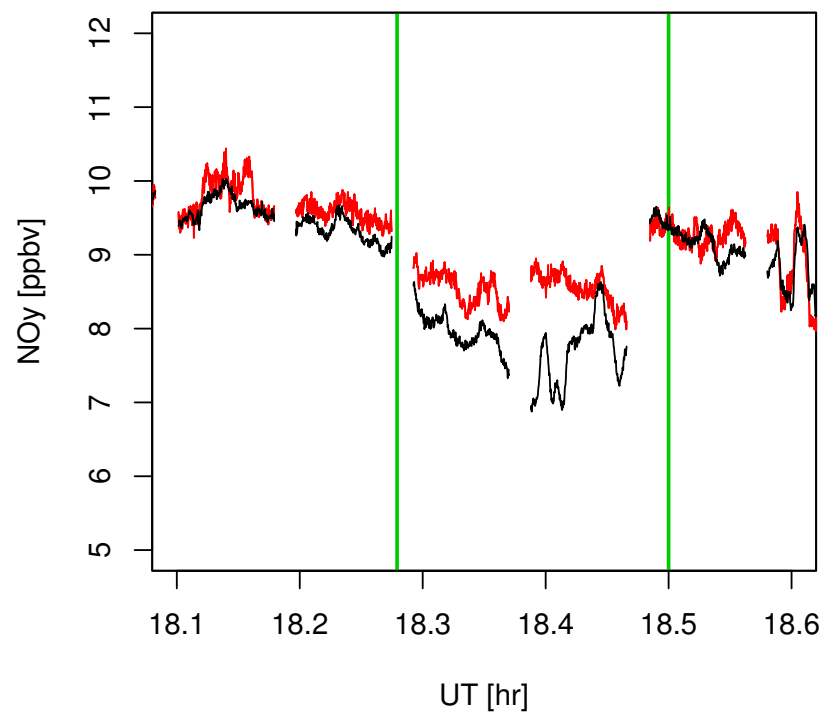

Fig. 3. Measured gas-phase plus $3.6 \times$ particle-phase (red line) and gas-phase (black line) $\mathrm{NO}_{\mathrm{y}}$ measured by the SIOUX instrument around the second PSC event on the flight on 8 February 2003. The green lines denote the edges of the region of PSCs marked by the green line in Fig. 2.

tribution, it was not operational during the part of the flight discussed below.

The SIOUX instrument (Schmitt, 2003; Voigt et al., 2005) located in the right wing pod of the aircraft M55 Geophysica has two inlets, which are especially designed for PSC measurements. Particle- and gas-phase $\mathrm{NO}_{\mathrm{y}}\left(\right.$ total $\mathrm{NO}_{\mathrm{y}}$ ) are detected using a forward facing inlet. The measured particle number density is enhanced due to anisokinetic sampling of the particles, the enhancement factor is dependent on pressure and particle size. The rear facing inlet primarily measures the gas phase; particles with diameters $>0.2 \mu \mathrm{m}$ are excluded due to inertia. Inside the inlets the particles evaporate, $\mathrm{NO}_{\mathrm{y}}$ is catalytically reduced to $\mathrm{NO}$, and the subsequent reaction of $\mathrm{NO}$ with ozone is measured with a chemiluminiscence detector. Nitric acid content of the particles is derived by subtracting the gas phase $\mathrm{NO}_{\mathrm{y}}$ from the total $\mathrm{NO}_{\mathrm{y}}$ and correcting for the particle enhancement. In this work, we use an oversampling factor of 3.6 for particles smaller than $0.3 \mu \mathrm{m}$ at pressures near $50 \mathrm{mbar}$, derived from inlet simulations (Krämer and Afchine, 2004). The oversampling factor increases for larger particles and decreases for lower pressures.

Measurements taken by the SIOUX instrument during this flight are shown in Fig. 3. The discrepancies between the total (red line) and gas-phase (black line) $\mathrm{NO}_{\mathrm{y}}$ occur when particles are present. We shall concentrate on the second, Northern, PSC event: denoted by the green lines in Figs. 2 and 3. The section of the flight that passes through this PSC was in the direction of, and practically parallel to, the local wind; this allows us to use the flight to construct a quasi- 


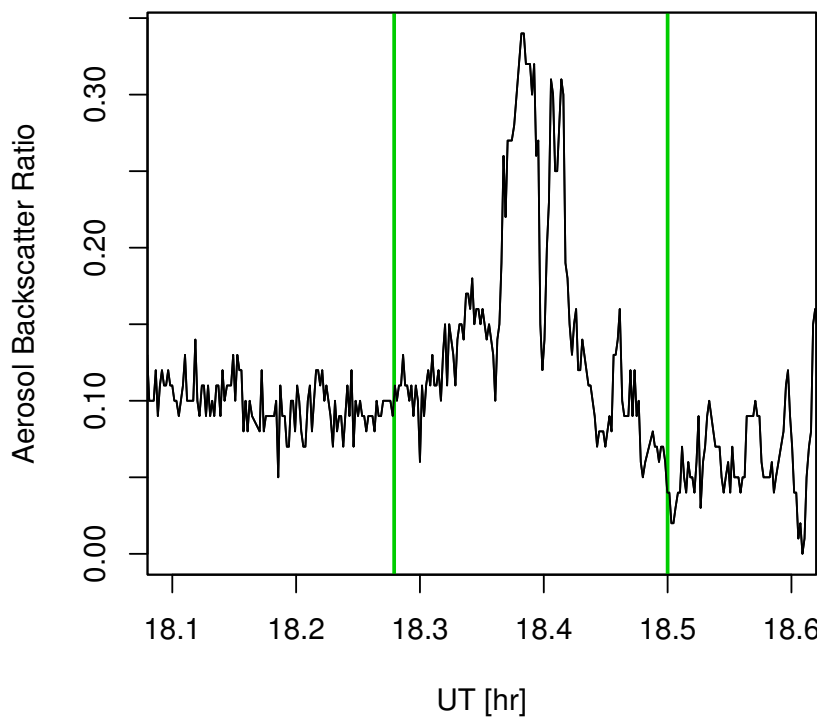

Fig. 4. Aerosol backscatter ratios measured by the MAS instrument. The green lines denote the edges of the region of PSCs marked by the green line in Fig. 2 .

lagrangian trajectory. We will not use the earlier PSC event (denoted by the blue line in Fig. 2) for a case study. This is done because the magnitudes of the MAS and SIOUX data within this event are not as great as those of the later event, to the degree that the signal in the SIOUX data is below the instruments detection limit. Additionally, the flight path of the Geophysica is not parallel to the wind direction throughout all of the earlier PSC observations, and so is not suitable for use within quasi-lagrangian trajectories.

The MAS instrument (Adriani et al., 1999) is an optical backscatter sonde, which measures aerosol backscatter and depolarization. Measurements cover a volume of air some 2$30 \mathrm{~m}$ starboard of the nose of the aircraft, with a peak signal at 3-5 $\mathrm{m}$ from the aircraft (which is the signal we will use for this work). The instrument is, therefore, a close-range remote sensor rather than a truly in-situ sensor. However, the range of the instrument is short enough that we can compare the results with in-situ measurements. The MAS instrument uses the wavelengths $532 \mathrm{~nm}$ and $1064 \mathrm{~nm}$, however the $1064 \mathrm{~nm}$ data was very noisy during this flight, so we will just use the $532 \mathrm{~nm}$ data. Measurements taken by the MAS instrument are shown in Fig. 4. This shows an increase in backscatter within the mountain-wave event, indicating an increase in the mass of the aerosol phase. Volume depolarisation at $532 \mathrm{~nm}$ was also measured by MAS, and showed no signal above background during the PSC eventshown in Fig. 4, indicating that the particles are liquid.

To create trajectories for our model we shall use temperature and pressure measurements made during the flight. Insitu measurements of these were made by the Geophysica's navigational data system (UCSE) and the MTP instrument.

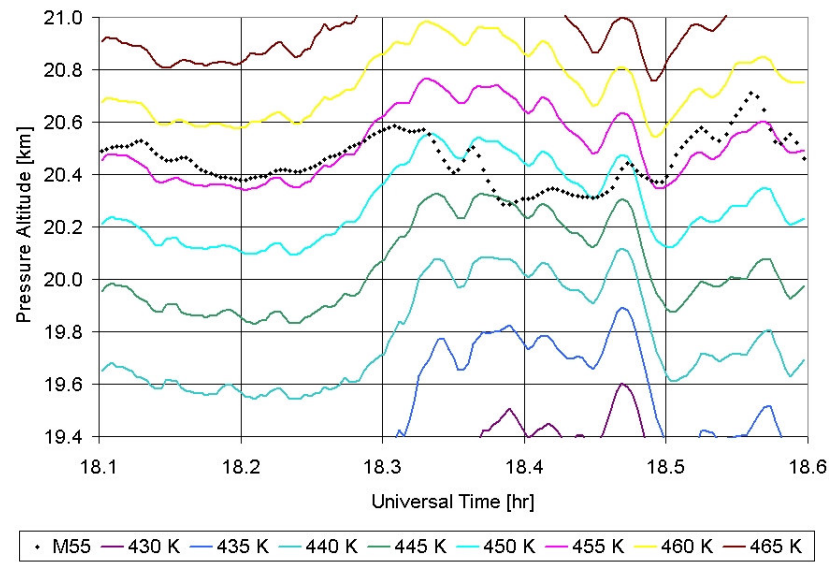

Fig. 5. Comparison of the pressure altitude of the Geophysica-M55 during the flight on the 8 February 2003 (black diamonds) with the pressure altitudes of isentropic surfaces (coloured solid lines) at $5 \mathrm{~K}$ intervals.

Additionally the variations in temperature within $5 \mathrm{~km}$ of the flight path altitude can be reliably obtained using the MTP measurements - the estimated errors in temperature relative to radiosondes are $\pm 0.5 \mathrm{~K}$ at flight level, less than $\pm 1.0 \mathrm{~K}$ within $2.2 \mathrm{~km}$ of flight level, and less than $\pm 2.0 \mathrm{~K}$ within $6 \mathrm{~km}$ of flight level. Using this data we compare the changes in the aircraft pressure altitude with those of the isentropic surfaces within the mountain wave (Fig. 5). Before the mountain wave the aircraft flies just above the $455 \mathrm{~K}$ isentrope, following its profile well. Within the mountain wave $(t \approx 18.27-18.5 \mathrm{~h})$, however, the aircraft drops about $10 \mathrm{~K}$ in potential temperature, before returning to roughly follow the $455 \mathrm{~K}$ isentrope again. These changes in potential temperature mean that the aircraft trajectory is not perfectly lagrangian; in the work below we will investigate the influence of variations in flight potential temperature on our attempts to replicate the $\mathrm{NO}_{\mathrm{y}}$ observations.

Comparisons of the UCSE data with measurements from the MTP show that, on average over the whole campaign, $\mathrm{T}_{\mathrm{UCSE}}=\mathrm{T}_{\mathrm{MTP}}-1.14 \mathrm{~K}$. For the 8 February flight this difference becomes $\mathrm{T}_{\mathrm{UCSE}}=\mathrm{T}_{\mathrm{MTP}}-1.63 \mathrm{~K}$. The MTP data are calibrated using measurements from radiosondes launched close to the flight path of the Geophysica and so are likely to be the most reliable temperature measurements; however the higher temporal resolution of the UCSE data is useful for our work, and so we will use this for our trajectories, although with corrections to bring the temperature in line with the MTP measurements.

\section{Model details}

We will use two box models to calculate the evolution of, and heterogeneous reactions on, the aerosol along a trajectory passing through the mountain wave. The first uses the 
parameterisation of Carslaw et al. (1995) to calculate the composition of STS in meta-stable equilibrium with the gasphase, from which we calculate the aerosol surface area for a prescribed particle number density. The second, MADVEC, describes the dynamics of condensational growth of liquid PSC particles, using the advection of mass components in radius-space (Pilinis, 1990) driven by differences between ambient partial pressures and the equilibrium vapour pressures parameterised by Luo et al. (1995). This scheme allows us to treat particle growth as the advection of mass in sizespace using fluid dynamical methods (see Lowe et al., 2003, for more details).

\subsection{Heterogeneous chemical reactions}

To the box models we have added parameterisations of heterogeneous reactions for the release of $\mathrm{Cl}_{2}$ and $\mathrm{HOCl}$ :

$$
\begin{aligned}
\mathrm{ClONO}_{2}+\mathrm{H}_{2} \mathrm{O}(\mathrm{l}) & \rightarrow \mathrm{HOCl}+\mathrm{HNO}_{3}(\mathrm{aq}), \\
\mathrm{ClONO}_{2}+\mathrm{HCl}(\mathrm{aq}) & \rightarrow \mathrm{Cl}_{2}+\mathrm{HNO}_{3}(\mathrm{aq}) \\
\mathrm{HOCl}+\mathrm{HCl}(\mathrm{aq}) & \rightarrow \mathrm{Cl}_{2}+\mathrm{H}_{2} \mathrm{O}(\mathrm{l})
\end{aligned}
$$

No gas-phase homogeneous reactions have yet been incorporated into the box models; so we do not currently model the photolytic conversion of $\mathrm{Cl}_{2}$ into $\mathrm{ClO}$, or the re-combination of $\mathrm{ClO}$ and $\mathrm{NO}_{2}$ to form $\mathrm{ClONO}_{2}$. These processes would not be relevant for these test-cases due to the high solar zenith angle; which increased from $111.5^{\circ}$ to $114^{\circ}$ during the passage of the Geophysica through the second PSC event (see Fig. 2).

There are no parameterisations for the rates of Reactions (R1)-(R3) on STS; instead we will use the parameterisations for binary sulphate solutions calculated by Shi et al. (2001). Their parameterisations are based on the water activity of the binary solution. To use their solution we simply insert the water activity of the STS droplets.

This method may, however, lead to an over estimation of the production rates of $\mathrm{Cl}_{2}$ and $\mathrm{HOCl}$ during our test-cases. Hanson (1998) has compared measured uptake coefficients for Reactions (R1) and (R2) on ternary $\mathrm{HNO}_{3} / \mathrm{H}_{2} \mathrm{SO}_{4}$ solutions with the calculated coefficients for binary sulphate solutions of the same water activity. He found that the uptake coefficients for ternary solutions were typically $30-50 \%$ less than would be expected for binary solutions with the same water activity. In addition we should note that the uptake coefficients given by the parameterisation of Shi et al. (2001) are, generally, greater than those used by Hanson (1998), which will increase any over-prediction in production rates (see Shi et al., 2001, Fig. 6, for comparison).

In both box-models we will treat $\mathrm{ClONO}_{2}, \mathrm{HOCl}$ and $\mathrm{HCl}$ as purely gas-phase species; principally because the calculations of Shi et al. (2001) use the gas-phase concentration of $\mathrm{HCl}$, and include terms to account for the depletion of $\mathrm{HCl}$ in the condensed-phase. However, because of the relatively small saturation ratios of $\mathrm{HCl}$, this assumption of equilibrium
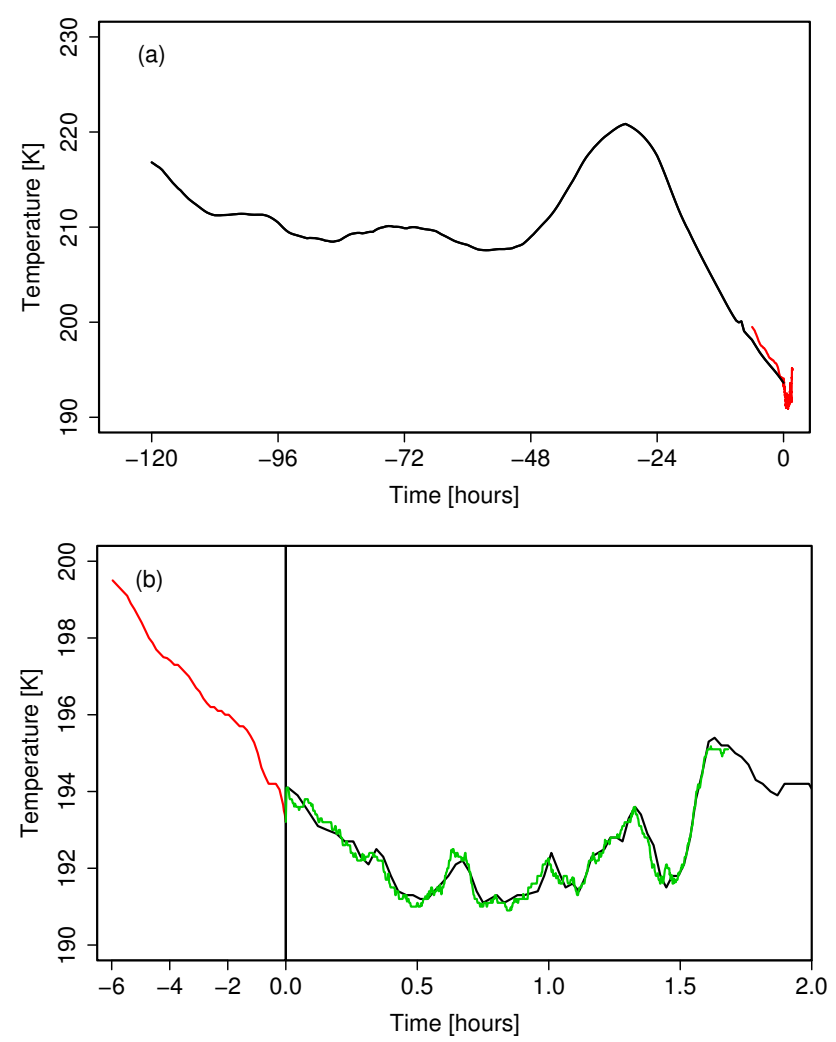

Fig. 6. (a) Temperature profile of the synoptic-scale (black line) back trajectory; the quasi-lagrangian trajectory used for the model runs is included for comparison (red line). (b) The quasi-lagrangian trajectory (combined red and green line) compared with the MTP temperature derived from the profile along the flight path (black line). The first (red) section of the trajectory is generated from a hindcast made using the MM5 model. The second (green) section is generated from the Geophysica flight data, the temperature is $\mathrm{T}_{\mathrm{UCSE}}+1.5 \mathrm{~K}$. Maximum cooling rates during the composite $\mathrm{T}_{\mathrm{UCSE}}+1.5 \mathrm{~K}_{\text {are }} 0.04 \mathrm{Ks}^{-1}$ over $5 \mathrm{~s}$ and $0.004 \mathrm{Ks}^{-1}$ over $900 \mathrm{~s}$.

is not unreasonable. Any gains or losses of $\mathrm{H}_{2} \mathrm{O}$ or $\mathrm{HNO}_{3}$ by reaction are applied to the condensed phase, however these are not large enough to make any significant difference to particle compositions.

\section{Test case settings}

\subsection{Trajectories}

Synoptic-scale back trajectories (based on ECMWFanalysis; http://badc.nerc.ac.uk/data/ecmwf-trj/) from the start of the second PSC event show that the temperature of the air-parcel was above $200 \mathrm{~K}$ for a period of at least 10 $120 \mathrm{~h}$ before the mountain wave event (Fig. 6a). As such we can assume that any PSC particles observed within the mountain wave event are less than 10-15 h old. 

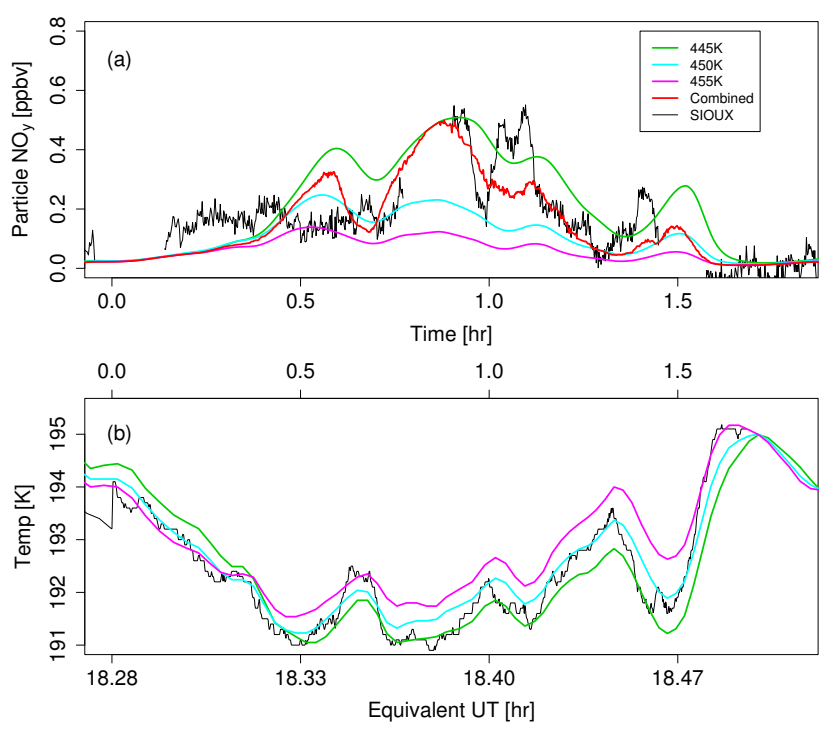

Fig. 7. (a) $\mathrm{NO}_{\mathrm{y}}$ content of the condensed phase for our nonequilibrium model along the isentropes measured by the MTP instrument (green, light blue and purple lines, as identified in the legend), combined $\mathrm{NO}_{\mathrm{y}}$ content along the aircraft trajectory from the isentrope data (red line), and measured by the SIOUX instrument (black line). (b) The temperature profiles along the isentropic trajectories (green, cyan and purple lines as identified in the legend in Fig. 7a), as well as the $\mathrm{T}_{\mathrm{UCSE}}+1.5 \mathrm{~K}$ temperature profile. Note that, because of the method we use to expand the timescale, the relationship between model time and the equivalent UT is not linear.

We have used two methods to generate trajectories for our models. In the first we have combined a $6 \mathrm{~h}$ MM5 backtrajectory (Wernli and Davis, 1997) with adapted temperature and pressure measurements from the Geophysica aircraft (Fig. 6b). To account for the differences between the aircraftand wind-speeds we have multiplied the timescale of the aircraft data by the ratio of the aircraft true airspeed to wind speed at each data point (using aircraft ground-speed for the conversion increases the time in the lee-wave by another 15 $\%$ but makes little difference to the overall results). Scaling the air-speed to the wind-speed increases the time-frame of the measurements by a factor of 7-8. To account for differences between UCSE and MTP (see Sect. 3 ), we add $1.5 \mathrm{~K}$ to

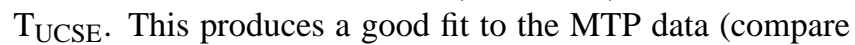
the green ( $\left.\mathrm{T}_{\mathrm{UCSE}}+1.5 \mathrm{~K}\right)$ and black (MTP) lines in Fig. $6 \mathrm{~b}$ ), allowing us to retain the higher temporal resolution of the UCSE data.

However, as discussed above (see Sect. 3), the trajectory followed by the aircraft within the gravity wave was not isentropic. To study what influence this will have on modelling the observations we will also use four isentropic trajectories along the $445 \mathrm{~K}, 450 \mathrm{~K}, 455 \mathrm{~K}$ and $460 \mathrm{~K}$ surfaces (see Fig. 5) - derived from the MTP data.

It should be noted that, within the mountain wave, neither the MM5 model nor the ECMWF analysis show tem- peratures as low as $192 \mathrm{~K}$. Without temperatures this low, the STS droplets will not grow very much, and there is little difference between the equilibrium and microphysical models. Hence, using these trajectories for model runs would not provide any extra information.

\subsection{Model initialisation}

We initialise our microphysical aerosol model using 4.8 ppmv $\mathrm{H}_{2} \mathrm{O}, 8.1$ ppbv $\mathrm{HNO}_{3}, 0.5$ ppbv $\mathrm{H}_{2} \mathrm{SO}_{4}$; giving a log-normal particle distribution with mode radius $0.065 \mu \mathrm{m}$, width 1.8 , and number density of $10 \mathrm{~cm}^{-3}$ at a temperature of $199.5 \mathrm{~K}$ and pressure of 58.12 mbar. The $\mathrm{H}_{2} \mathrm{O}$ and $\mathrm{HNO}_{3}$ mixing ratios are approximations taken, respectively, from FISH and SIOUX data during the second PSC event. The $\mathrm{H}_{2} \mathrm{SO}_{4}$ mixing ratio and particle number density are based on standard values for this part of the stratosphere. In the stratosphere, reactive nitrogen $\left(\mathrm{NO}_{\mathrm{y}}\right)$ is composed of $\mathrm{NO}, \mathrm{NO}_{2}$, $\mathrm{NO}_{3}, \mathrm{~N}_{2} \mathrm{O}_{5}, \mathrm{HONO}, \mathrm{HO}_{2} \mathrm{NO}_{2}, \mathrm{HNO}_{3}, \mathrm{PAN}$, and $\mathrm{ClONO}_{2}$. For this work, however, we will assume that all of the particulate $\mathrm{NO}_{\mathrm{y}}$ is in the form of $\mathrm{HNO}_{3}$.

To initialise the chlorine compounds within our model we will use the scheme of Schauffler et al. (2003), which is based on data collected during the SOLVE campaign in JanuaryMarch 2000. Using this scheme we calculate the total inorganic chlorine based on the $\mathrm{N}_{2} \mathrm{O}$ content of the air parcel (determined by HAGAR to be approximately $135 \mathrm{ppb}$ within the second PSC event), which is then divided between $\mathrm{ClO}_{\mathrm{x}}$, $\mathrm{ClONO}_{2}, \mathrm{HCl}$ and $\mathrm{HOCl}$. Values for $\mathrm{ClO}_{\mathrm{x}}\left(\mathrm{ClO}+2 \mathrm{Cl}_{2} \mathrm{O}_{2}\right)$ and $\mathrm{ClONO}_{2}$ are derived from averages of HALOX measurements during, and immediately before, the PSC event. The $\mathrm{HOCl}$ mixing ratio is an estimate informed by previous modelling studies, while the $\mathrm{HCl}$ is simply the remainder of the total inorganic chlorine. Our total inorganic chlorine mixing ratio is $2800 \mathrm{ppt}$; with $300 \mathrm{ppt} \mathrm{ClO}_{\mathrm{x}}, 500 \mathrm{ppt} \mathrm{ClONO}_{2}$, $100 \mathrm{ppt} \mathrm{HOCl}$ and $1900 \mathrm{ppt} \mathrm{HCl}$. The $\mathrm{ClO}_{\mathrm{x}}$ data are uncertain by $30 \%$. Although the results are sensitive to these uncertainties, the relative magnitudes of the results are less so, and thus neither are our conclusions.

\section{Results}

\subsection{Particle composition}

In Fig. 7 the particle-phase $\mathrm{NO}_{\mathrm{y}}$ content of our microphysical model (green, light blue and purple lines, as identified in the legend) is compared with that measured by the SIOUX instrument (black line). The SIOUX instrument does not distinguish particles with radii $<0.1 \mu \mathrm{m}$ from the gas phase (see Sect. 3), leading to an underestimation of the $\mathrm{NO}_{\mathrm{y}}$ content of the condensed phase. To account for this when making comparisons between SIOUX and model data, the $\mathrm{NO}_{\mathrm{y}}$ content of model particles with radii $<0.1 \mu \mathrm{m}$ is not included in the condensed phase $\mathrm{NO}_{\mathrm{y}}$ shown. The effect of this is to reduce the modelled $\mathrm{HNO}_{3}$ content by $5-15 \%$. 
From Fig. 7 we see that the model runs along the $450 \mathrm{~K}$, and $455 \mathrm{~K}$ isentropes, as well as that run along the $460 \mathrm{~K}$ isentrope (not shown), produce quite low particle-phase $\mathrm{NO}_{\mathrm{y}}$ contents, whereas that produced by the $445 \mathrm{~K}$ model run is much higher - with a maximum of $\approx 0.5 \mathrm{ppbv} \mathrm{NO}_{\mathrm{y}}$ in the particle-phase, comparable with the maxima of the SIOUX data, and $\leq 0.3 \mathrm{ppbv}$ for the other model runs. The greater differences between the output from the $445 \mathrm{~K}$ and $450 \mathrm{~K}$ model runs, as opposed to, for example, the $450 \mathrm{~K}$ and $455 \mathrm{~K}$ runs, occur because these two trajectories straddle the narrow range of temperatures over which the liquid aerosol particles change composition from binary sulphate to ternary solutions.

Although the $445 \mathrm{~K}$ model run is the best at replicating the magnitude of the SIOUX measurements, it does not fully capture some of the rapid changes in $\mathrm{NO}_{\mathrm{y}}$ content measured by the SIOUX instrument. As discussed above, these changes occur as the aircraft crosses isentropic levels, so sampling air-parcels with different temperature histories. To simulate this we have calculated the expected particle-phase $\mathrm{NO}_{y}$ content along the $\mathrm{T}_{\mathrm{UCSE}}+1.5 \mathrm{~K}$ trajectory by interpolating between the neighbouring two isentropic trajectories based on the calculated potential temperature for the $\mathrm{T}_{\mathrm{UCSE}}+1.5 \mathrm{~K}$ trajectory (where the trajectory passes outside of this range of potential temperatures, e.g. at time $t \approx 0.9 \mathrm{~h}$, we simply use the value for the nearest isentropic trajectory). The result is shown by the red line in Fig. 7a, and it retains the maximum $\mathrm{NO}_{\mathrm{y}}$ content of approximately $0.5 \mathrm{ppbv}$ of the $445 \mathrm{~K}$ model run, although for the majority of the mountain wave event the $\mathrm{NO}_{\mathrm{y}}$ content is closer to the $450 \mathrm{~K}$ model run.

In Fig. 8a we compare the resulting particle-phase $\mathrm{NO}_{\mathrm{y}}$ content from the combination of the isentropic trajectories with that resulting from simply running our microphysical model along the $\mathrm{T}_{\mathrm{UCSE}}+1.5 \mathrm{~K}$ trajectory. The $\mathrm{NO}_{\mathrm{y}}$ content of $\mathrm{T}_{\mathrm{UCSE}}+1.5 \mathrm{~K}$ model run (blue line) is generally of a similar magnitude to that calculated from the isentropic models (red line), although with lower maxima. This is primarily due to the differences in the aerosol size distributions of the two runs. In the quasi-lagrangian model run, a higher proportion of the condensed phase $\mathrm{NO}_{\mathrm{y}}$ is in particles with radii $<0.1 \mu \mathrm{m}$ than is the case for the combined result of the isentropic model runs. So, when we eliminate these particles, for comparison with the SIOUX data, the quasi-lagrangian test case is more severely affected. The difference is due to the temperature history of the quasi-lagrangian model run being warmer than that of the $445 \mathrm{~K}$ isentropic model run, which dominates the combined results at the observed maxima. However the difference between these model runs is small compared with their difference to the equilibrium calculations (grey line). Overall both microphysical model runs are better than the equilibrium calculations at capturing the magnitude of the SIOUX measurements. The equilibrium calculations are, however, better at representing the shape and magnitude of some observed features after $t=1 \mathrm{~h}$.
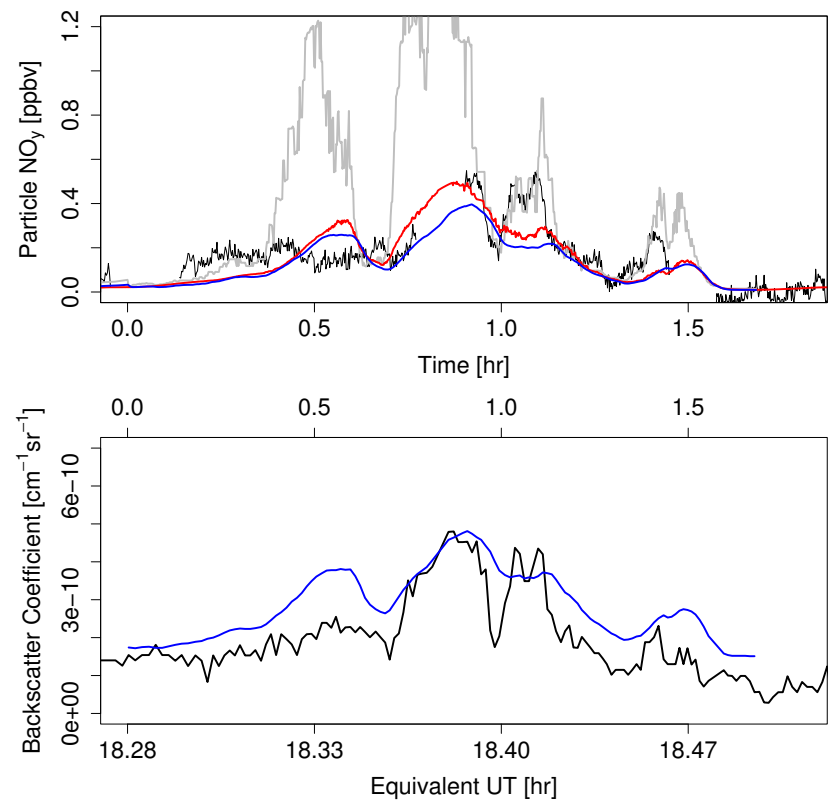

Fig. 8. (a) $\mathrm{NO}_{\mathrm{y}}$ content of the condensed phase for our microphysical model (blue line) and equilibrium calculations (grey line) along the $\mathrm{T}_{\mathrm{UCSE}}+1.5 \mathrm{~K}$ trajectory, compared with those measured by the SIOUX instrument (black line) and calculated along the $\mathrm{T}_{\mathrm{UCSE}}+1.5 \mathrm{~K}$ trajectory using the data from the isentropic trajectories shown in Fig. 7 (red line). (b) Backscatter coefficients calculated from the MAS data (black line) and our microphysical model (blue line). The uncertainty of the MAS data varies around $5.5 \times 10^{-12} \mathrm{~cm}^{-1} \mathrm{sr}^{-1}$; around $3 \%$ of the signal within the mountain wave.

In Fig. 8b we compare the backscatter coefficients from the MAS data (black line) and those calculated from our microphysical model (blue line). For these calculations we assume a refractive index of 1.43 for STS droplets (in line with the calculations of Luo et al., 1996). The peak values of the measured and modelled signals are of the same magnitude, and have a good temporal fit. However, throughout the rest of the mountain-wave event the modelled values are higher than those measured. This is because the stratospheric aerosol burden was lower than the standard values we used to initialise our model (see Sect. 5.2).

However we must note that our microphysical model does not simulate some features of the SIOUX and MAS measurements very well. Most notable is the uptake of $\mathrm{NO}_{\mathrm{y}}$ predicted by the models and equilibrium calculations at $t \approx 0.5 \mathrm{~h}$, which is not seen in the measurements. Because of the detection limit of 0.3 ppbv $\mathrm{NO}_{\mathrm{y}}$ for the SIOUX instrument (any signal features below this limit could be either real or artifact), we cannot be certain of the magnitude of the discrepancy between the models and measurements. However the absence of this feature within the measured mountain-wave PSC is supported by the MAS data (Fig. 8b). The most likely cause of these discrepancies are the simplifications and approxi- 

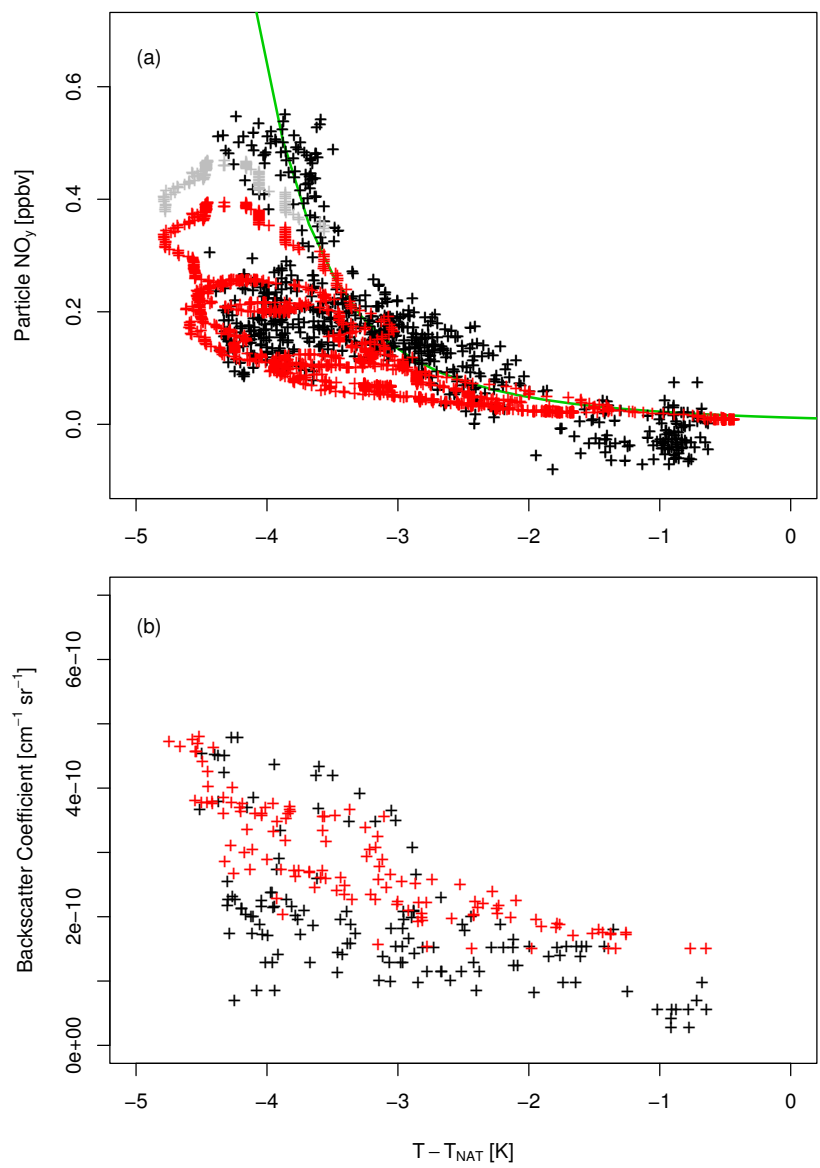

Fig. 9. (a) $\mathrm{NO}_{\mathrm{y}}$ content of the condensed phase, within the mountain wave, for our microphysical model (red crosses) and the SIOUX data (black crosses) against $\mathrm{T}-\mathrm{T}_{\mathrm{NAT}}$. The green line represents the equilibrium composition of STS at the mixing ratios mentioned in Sect. 5.2 and at a pressure of 50 mbar. The grey crosses represent the total $\mathrm{NO}_{\mathrm{y}}$ content of the condensed phase of our microphysical model including particles with radii $<0.1 \mu \mathrm{m}$, between $0.84-0.98 \mathrm{~h}$. (b) Aerosol backscatter coefficients within the mountain wave for our microphysical model (red crosses) and the MAS data (black crosses) against $\mathrm{T}-\mathrm{T}_{\mathrm{NAT}}$.

mations which we have had to make in order to create the model trajectories. Because of the transient, non-stationary nature of the mountain waves on this day we are unable to get a better temporal fit to the observed data. Note, however, that the discrepancy between the equilibrium model and the observations at $\mathrm{t} \approx 0.5 \mathrm{~h}$ is even greater than that between microphysical model and observations.

To remove the time-dependence of the data we have plotted them against $\mathrm{T}-\mathrm{T}_{\mathrm{NAT}}$ (Fig. 9). $\mathrm{T}_{\mathrm{NAT}}$ is calculated using the parameterisation of Hanson and Mauersberger (1988). For all data sets temperature and pressure are taken from the flight data. For data from our microphysical model (red and grey crosses) we calculate $\mathrm{T}_{\mathrm{NAT}}$ using the fixed values of $\mathrm{H}_{2} \mathrm{O}$ and $\mathrm{HNO}_{3}$ given in Sect. 5.2. For the measured data (black crosses) we use the FISH and corrected SIOUX data to calculate $\mathrm{T}_{\mathrm{NAT}}$. Because of these different methods of calculating $\mathrm{T}_{\mathrm{NAT}}$ the spread of $\mathrm{T}-\mathrm{T}_{\mathrm{NAT}}$ values for the two data sets are slightly different. We note that the aerosol model seems to have been subjected to a slightly wider range of values of $\mathrm{T}-\mathrm{T}_{\mathrm{NAT}}$, although some of this difference could be due to data gaps (calibration cycles) in the SIOUX measurements.

Comparing the measured (black crosses) and modelled (red crosses) particle $\mathrm{NO}_{\mathrm{y}}$ data (Fig. 9a), we see a reasonable co-location of the two datasets at higher temperatures, although the modelled particle $\mathrm{NO}_{\mathrm{y}}$ is about $0.15 \mathrm{ppbv}$ below the measurement values at lower temperatures. We have previously noted that the aerosol size distributions during the quasi-lagrangian run are smaller than those from the isentropic model run which dominates at these low temperatures. Consequently more $\mathrm{NO}_{\mathrm{y}}$ is in the smaller particles, so adding the $\mathrm{NO}_{\mathrm{y}}$ from these particles back into our results (cf. grey crosses in Fig. 9a) does go someway to reducing the disparity. This is a reasonable approach if we assume that the measured particles have a temperature history more similar to the isentropic trajectories, in which case they will be larger and so there will be less $\mathrm{NO}_{\mathrm{y}}$ in particles with radii $<0.1 \mu \mathrm{m}$. The comparison of the measured (black crosses) and modelled (red crosses) backscatter coefficients shown in Fig. 9b confirms the good agreement between modelled and measured backscatter ratios, particularly as $\mathrm{T}-\mathrm{T}_{\mathrm{NAT}}$ becomes more negative.

The results from the combined isentropic and $\mathrm{T}_{\mathrm{UCSE}}+1.5 \mathrm{~K}$ microphysical model runs are, within our limitations, reasonable simulations of the SIOUX and MAS measurements. The mountain waves seen on the 8 February 2003 were not stable, so trajectories based on the aircraft data will not be perfect simulations of the actual isentropic trajectories. Additionally we have used mixing ratios based on averaged measurements within the mountain wave, which is a simplification.

\subsection{Heterogeneous chemical reactions}

Using the microphysical model run and the equilibrium calculations, along the $\mathrm{T}_{\mathrm{UCSE}}+1.5 \mathrm{~K}$ trajectory, we shall now examine the production of $\mathrm{Cl}_{2}$ during the model runs. $\mathrm{Cl}_{2}$ production is determined by the heterogeneous reaction rates (influenced by particle composition) and the aerosol surface areas and volumes available for these reactions to occur on. We calculate the reaction rates using the water activity of the modelled solutions (see Sect. 4.1). This is equal to unity for the equilibrium calculations, and close to unity for the microphysical model due to the short relaxation times of water (see Sect. 1). Thus, although differences in particles composition are large between the microphysical and equilibrium calculations (Fig. 10), any differences in the reaction rates of the two models directly due to particle composition will be minor.As discussed in Sect. 4.1, this may not remain the 

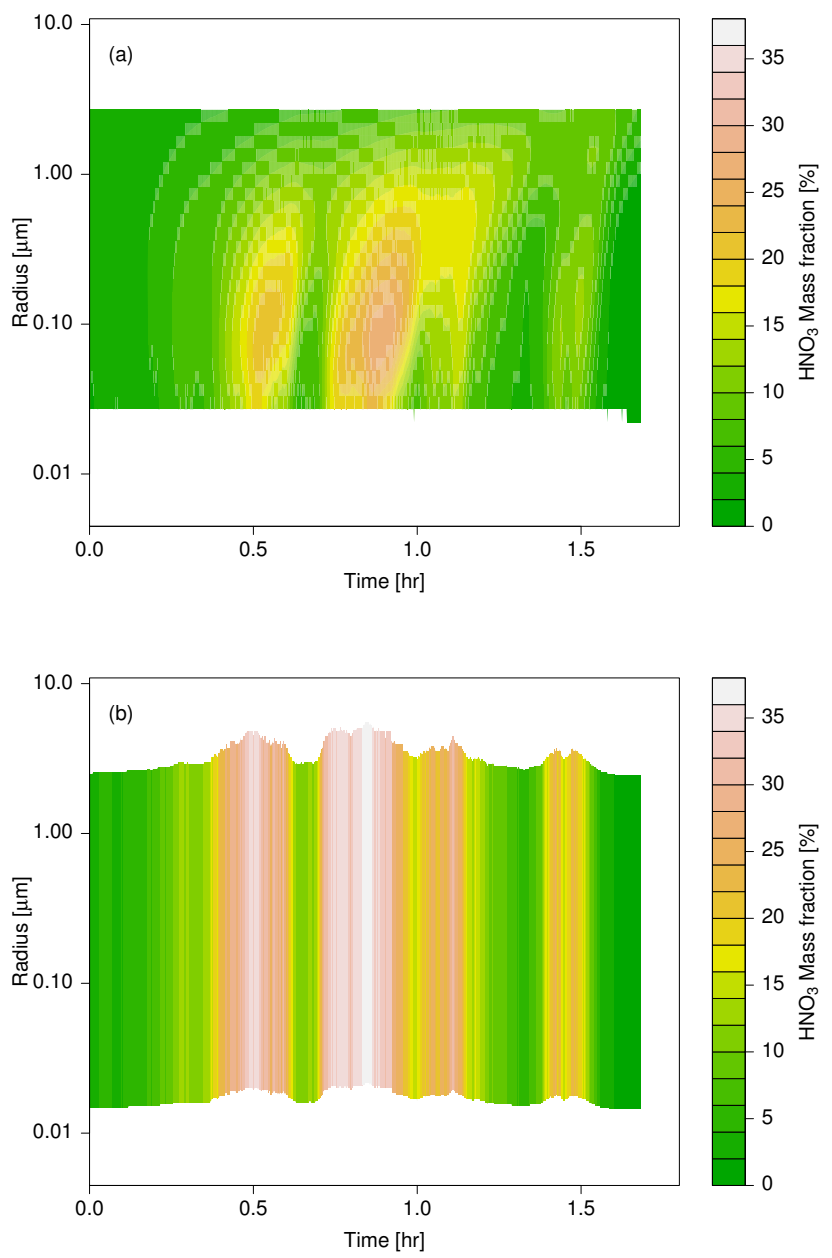

Fig. 10. The changes in $\mathrm{HNO}_{3}$ mass fraction across the particle size range during the $\mathrm{T}_{\mathrm{UCSE}}+1.5 \mathrm{~K}$ model run shown in Fig. 8 for (a) our microphysical model and (b) the equilibrium model.

case if or when a parameterisation for chlorine activation in ternary solutions is developed.

The greatest cause of differences in $\mathrm{Cl}_{2}$ production between the models are the differences in aerosol volume and surface area (Fig. 11). These are both larger in the equilibrium calculations (red line) than in the microphysical model (blue line). The differences in aerosol volume (Fig. 11b) are less than those in condensed $\mathrm{NO}_{\mathrm{y}}$ content (Fig. 8a) due to the uptake of water by the particles in the microphysical model compensating for the reduced uptake of nitric acid. The differences in aerosol surface area (Fig. 11a) between the models are also significantly less than the differences in condensed $\mathrm{NO}_{\mathrm{y}}$ content. This is because the smallest particles in the microphysical model grow most, unlike the equilibrium model for which particle growth is not size-dependent, creating a greater increase in surface area for the equivalent volume increase.

The loss rates of the heterogeneous reactions can be proportional to either the aerosol volume or surface area, de-
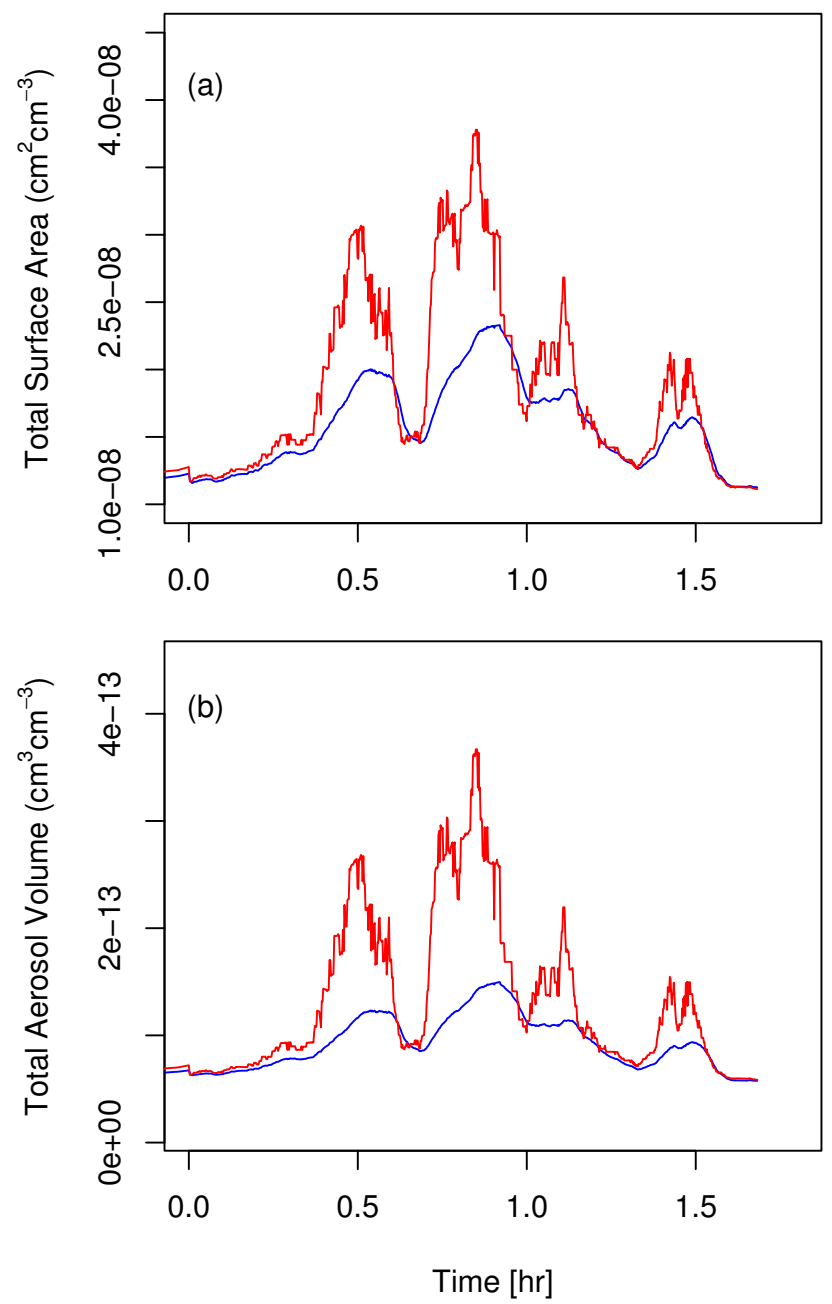

Fig. 11. Comparisons of the total aerosol (a) surface area and (b) volume produced from the equilibrium (red lines) and dynamic (blue lines) models in the $\mathrm{T}_{\mathrm{UCSE}}+1.5 \mathrm{~K}$ test case.

pending on the ratio of particle radius to reacto-diffusive length of the reaction (c.f. Shi et al., 2001). When the reactodiffusive length is much larger than the particle radius then the reaction rates are proportional to the particle volume; when the reacto-diffusive length is much smaller than the particle radius then the rates are proportional to the particle surface area. During the quasi-lagrangian test-cases the reacto-diffusive length is in the range $0.005-0.015 \mu \mathrm{m}$, increasing with decreasing temperature. The mode radius of the aerosol distribution for the microphysical model is in the range of $0.06-0.1 \mu \mathrm{m}$, roughly a factor of 10 greater than the reacto-diffusive length. Consequentually the loss rates will be determined principally by the aerosol surface area, with some influence from the aerosol volume. The influence of the aerosol volume will increase for the smallest particles $(\approx 0.02 \mu \mathrm{m})$ but do not dominate the loss rates in this test case. 

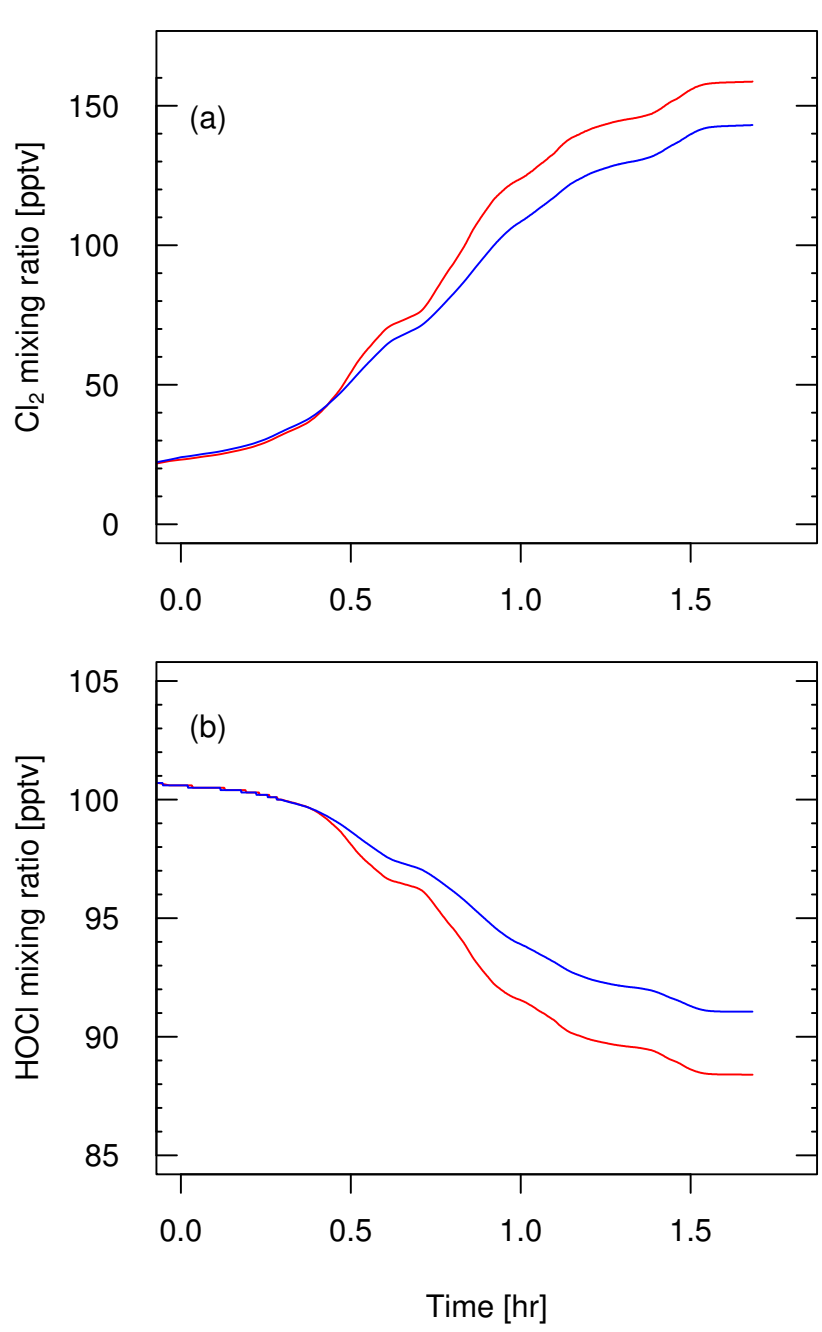

Fig. 12. Production of (a) $\mathrm{Cl}_{2}$ and (b) $\mathrm{HOCl}$ during the $\mathrm{T}_{\mathrm{UCSE}}+1.5 \mathrm{~K}$ model runs shown in Fig. 8. The blue line indicates the output from our microphysical model, the red line that from the equilibrium code.

The production of $\mathrm{Cl}_{2}$ and $\mathrm{HOCl}$ during the model run are shown in Fig. 12. The equilibrium code produces about $10 \%$ more $\mathrm{Cl}_{2}$ than the microphysical model (159 pptv, compared with $143 \mathrm{pptv}$ ). As discussed above, this difference is principally due to the greater aerosol surface area seen in the equilibrium model (Fig. 11a). Measurements of $\mathrm{ClO}_{\mathrm{x}}$ $\left(\mathrm{ClO}+2 \mathrm{Cl}_{2} \mathrm{O}_{2}\right)$ by the HALOX instrument show concentrations of around $300 \mathrm{pptv}$ during this section of the flight. However, because the solar zenith angle was so large (Fig. 2) no comparison can be made between the measured $\mathrm{ClO}_{\mathrm{x}}$ and the predictions of $\mathrm{Cl}_{2}$ production from the model.

\section{Conclusions}

On the 8 February 2003, during the EuPLEx campaign, in-situ measurements of condensed-phase $\mathrm{NO}_{\mathrm{y}}$ were made within mountain wave PSCs. Using dynamic microphysical, and equilibrium composition, models running along quasilagrangian trajectories - generated using flight data from the Geophysica, MM5 back-trajectories and MTP data - we have investigated the second, Northern, PSC event. We found that the particle-phase $\mathrm{NO}_{\mathrm{y}}$ measurements could be best represented by interpolating the $\mathrm{NO}_{\mathrm{y}}$ content calculated by our microphysical model along the isentropic trajectories created using the MTP data. However the $\mathrm{NO}_{\mathrm{y}}$ content predicted by our microphysical model using the $\mathrm{T}_{\mathrm{UCSE}}+1.5 \mathrm{~K}$ trajectory is comparable to that calculated using the MTP trajectories. Equilibrium calculations along the $\mathrm{T}_{\mathrm{UCSE}}+1.5 \mathrm{~K}$ trajectory overpredict the particle-phase $\mathrm{NO}_{\mathrm{y}}$ content in the first section of the mountain wave by up to a factor of 3 , although they are better at capturing the shape of the later measurements. These simulations of the mountain wave event are limited by the short-lived and non-stationary nature of the mountain waves, as well as by our assumptions of the homogeneity of the mixing ratios of atmospheric gases. Bearing these caveats in mind, we conclude that the fit of the dynamic model to the measurements is reasonable, and demonstrates the high degree of non-equilibrium in liquid PSCs formed by mountain waves. Within the simulated mountain wave our models produce $140-160$ pptv $\mathrm{Cl}_{2}$ (280-320 pptv $\mathrm{Cl})$. Unfortunately, the solar zenith angle during this period is such that we cannot make any direct comparisons between modelled and measured $\mathrm{ClO}_{\mathrm{x}}$ production; it would, however, be viable to make this comparison with measurements taken within similar mountain wave events occurring in sun light.

The differences in total aerosol mass between the two models are less than the differences in condensed-phase $\mathrm{NO}_{\mathrm{y}}$ would suggest, because of the lower $\mathrm{HNO}_{3}$ mass fractions of the dynamic model - which is due to a hysteresis effect in the evolution in composition of STS particles (Meilinger et al., 1995). The differences in the total aerosol surface areas are even smaller, because the mean particle radii of the dynamic model are smaller than those of the equilibrium model; consequently the equilibrium model only converts $10 \%$ more $\mathrm{Cl}_{2}$ than the dynamic model. The differences in aerosol mass between the models, and so the differences in $\mathrm{Cl}_{2}$ production, are very trajectory dependent. In this particular test case the average temperature within the mountain wave is $0.5-1.0 \mathrm{~K}$ above $\mathrm{T}_{\mathrm{STS}}$ (the narrow $(\Delta T<1 \mathrm{~K})$ temperature range at which the liquid aerosols change from a primarily binary sulphuric to a ternary composition). The drops in temperature below $\mathrm{T}_{\mathrm{STS}}$ are too brief for condensation of large amounts of $\mathrm{HNO}_{3}$ to occur, so overall the dynamic model produces smaller aerosol masses than the equilibrium model. As the average temperature decreases so should the differences in mass between the models. Hence this $10 \%$ difference in $\mathrm{Cl}_{2}$ production between the two models is not fixed; more research is required to determine the range of ratios which could be expected for typical stratospheric mountain wave events. 
The differences in $\mathrm{Cl}_{2}$ production, due to surface area differences, between the two models are less than the reductions we could expect if we used parameterisations for Reactions (R1)-(R3) designed for ternary solutions. It is not clear from the few data points collated by Hanson (1998) whether the magnitude of the reduction in $\mathrm{ClONO}_{2}$ uptake coefficients varies with the $\mathrm{HNO}_{3}$ content of the solution. Because of the hysteresis effect - where the liquid PSC particles closely follow the composition curve of the binary sulphate solution upon cooling, and follow that of the binary nitric acid solution upon warming (see Meilinger et al., 1995) - such a composition dependence of Reactions (R1)-(R3) would lead to a greater decrease of the rates in the equilibrium model than in the dynamic model, possibly to the point of eliminating, or even reversing, the differences between the models. There is therefore a need for more laboratory studies of the heterogeneous reaction rates on ternary sulphuric/nitric solutions and more airborne measurements of condensed $\mathrm{NO}_{\mathrm{y}}$ simultaneous with measurements of gasphase $\mathrm{ClO}_{\mathrm{x}}$.

Acknowledgements. Our thanks to F. Stroh and M. von Hobe for providing the HALOX data and for help with interpretation, M. Volk for providing the HAGAR data and for help with interpretation, and C. Schiller for providing the FISH data. Work performed at Lancaster University was supported by EU contract number EVK2-CT-2001-00119. Work performed at the Jet Propulsion Laboratory, California Institute of Technology, was carried out under a contract with the National Aeronautics and Space Administration. The ECMWF forecast and operational analyses were provided in the framework of the ECMWF special project "Influence of non-hydrostatic mountain waves on the stratosphere above Scandinavia" by one of the authors (A. Dörnbrack). We thank H. Wernli (University of Mainz, Germany) for his trajectory code. The mesoscale numerical simulations were performed on the NEC SX6 super computer of the German Climate Research Center (DKRZ) in Hamburg, Germany.

Edited by: K. Carslaw

\section{References}

Adriani, A., Cairo, F., Viterbini, M., Mandolini, S., Pulvirenti, L., and Di Donfrancesco, G.: Multi-wavelength aerosol scatterometer for airborne experiments to study the optical properties of stratospheric aerosol, J. Atmos. Ocean. Tech., 16, 1329-1336, 1999.

Browell, E. V., Butler, C. F., Ismail, S., Robinette, P. A., Carter, A. F., Higdon, N. S., Toon, O. B., Schoeberl, M. R., and Tuck, A. F.: Airborne lidar observations in the wintertime Arctic stratosphere: polar stratospheric clouds, Geophys. Res. Lett., 17, 385388, 1990.

Brune, W. H., Anderson, J. G., and Chan, K. R.: Insitu Observations of $\mathrm{ClO}$ in the Antarctic - ER-2 Aircraft results from $54^{\circ} \mathrm{S}$ to $72^{\circ}$ S Latitude, J. Geophys. Res., 94, 16 649-16 663, 1989.

Carslaw, K. S., Luo, B. P., Clegg, S. L., Peter, T., Brimblecombe, P., and Crutzen, P. J.: Stratospheric Aerosol Growth and $\mathrm{HNO}_{3}$
Gas Phase Depletion from Coupled $\mathrm{HNO}_{3}$ and Water uptake by Liquid Particles, Geophys. Res. Lett., 21, 2479-2482, 1994.

Carslaw, K. S., Luo, B., and Peter, T.: An analytic expression for the composition of aqueous $\mathrm{HNO}_{3}-\mathrm{H}_{2} \mathrm{SO}_{4}$ stratospheric aerosols including gas phase removal of $\mathrm{HNO}_{3}$, Geophys. Res. Lett., 22, 1877-1880, 1995.

Carslaw, K. S., Wirth, M., Tsias, A., Luo, B. P., Dörnbrack, A., Leutbecher, M., Volkert, H., Renger, W., Bacmeister, J. T., and Peter, T.: Particle microphysics and chemistry in remotely observed mountain polar stratospheric clouds, J. Geophys. Res., 103, 5785-5796, 1998.

Denning, R. F., Guidero, S. L., Parks, G. S., and Gary, B. L.: Instrument Description of the Airborne Microwave Temperature Profiler, J. Geophys. Res., 94, 16757-16765, 1989.

Dörnbrack, A., Leutbecher, M., Volkert, H., and Wirth, M.: Mesoscale forecasts of stratospheric mountain waves, Meteorol. Appl., 5, 117-126, 1998.

Dye, J. E., Baumgardner, D., Gandrud, B. W., Kawa, S. R., Kelly, K. K., Loewenstein, M., Ferry, G. V., Chan, K. R., and Gary, B. L.: Particle size distributions in Arctic polar stratsopheric clouds, growth and freezing of sulfuric acid droplets and implications for cloud formation, J. Geophys. Res., 97, 8015-8034, 1992.

Dörnbrack, A., Leutbecher, M., Kivi, R., and Kyrö, E.: Mountain wave induced record low stratospheric temperatures above northern Scandinavia, Tellus, 51A, 951-963, 1999.

Dörnbrack, A., Birner, T., Fix, A., Flentje, H., Meister, A., Schmid, H., Browell, E. V., and Mahoney, M. J.: Evidence for inertia gravity waves forming polar stratospheric clouds over Scandinavia, J. Geophys. Res., 107(D20), 8287, doi:10.1029/2001JD000452, 2002.

Drdla, K.: Applications of a Model of Polar Stratospheric Clouds and Heterogeneous Chemistry, PhD thesis, University of California, Los Angeles, 1996.

Drdla, K. and Schoeberl, M. R.: Microphysical modeling of the 1999-2000 Artic winter: 2. Chlorine activation and ozone depletion, J. Geophys. Res., 108(D5), 8319, doi:10.1029/2001JD001159, 2003.

Fahey, D. W., Gao, R. S., Carslaw, K. S., Kettleborough, J., Popp, P. J., Northway, M. J., Holecek, J. C., Ciciora, S. C., McLaughlin, R. J., Thompson, T. L., Winkler, R. H., Baumgardner, D. G., Gandrud, B., Wennberg, P. O., Dhaniyala, S., McKinney, K., Peter, T., Salawitch, R. J., Bui, T. P., Elkins, J. W., Webster, C. R., Atlas, E. L., Jost, H., Wilson, J. C., Herman, R. L., Kleinböhl, A., and von König, M.: The Detection of Large $\mathrm{HNO}_{3}$-Containing Particles in the Winter Artic Stratosphere, Science, 291, 10261031, 2001.

Hanson, D. and Mauersberger, K.: Laboratory Studies of the Nitrc Acid Trihydrate: Implications for the South Polar Stratosphere, Geophys. Res. Lett., 15, 855-858, 1988.

Hanson, D. R.: Reaction of $\mathrm{ClONO}_{2}$ with $\mathrm{H}_{2} \mathrm{O}$ and $\mathrm{HCl}$ in Sulfuric Acid and $\mathrm{HNO}_{3} / \mathrm{H}_{2} \mathrm{SO}_{4} / \mathrm{H}_{2} \mathrm{O}$ Mixtures, J. Phys. Chem. A, 102, 4794-4807, 1998.

Jones, R. L., Soloman, S., McKenna, D. S., Poole, L. R., Brune, W. H., Toohey, D. W., Anderson, J. G., and Fahey, D. W.: The Polar Stratospheric Cloud Event of January 24, 1989: Part 2, Photochemistry, Geophys. Res. Lett., 17, 541-544, 1990.

Kawa, S. R., Newman, P. A., Lait, L. R., Schoeberl, M. R., Stimpfle, R. M., Kohn, D. W., Webster, C. R., May, R. D., Baumgardner, D., Dye, J. E., Wilson, J. C., Chan, K. R., and Loewenstein, M.: 
Activation of chlorine in sulfate aerosol as inferred from aircraft observations, J. Geophys. Res., 102, 3921-3933, 1997.

Krämer, M. and Afchine, A.: Sampling characteristics of inlets operated at low $U / U_{0}$ ratios: new insights from computational fluid dynamics (CFX) modeling, J. Aerosol Sci., 35, 683-694, 2004.

Kühl, S., Dörnbrack, A., Wilms-Grabe, W., Sinnhuber, B.-M., Platt, U., and Wagner, T.: Observational evidence of rapid chlorine activation by mountain waves above northern Scandinavia, J. Geophys. Res., 109, D22309, doi:10.1029/2004JD004797, 2004.

Larsen, N., Knudsen, B. M., Rosen, J. M., Kjome, N. T., Neuber, R., and Kyro, E.: Temperature histories in liquid and solid polar stratospheric cloud formation, J. Geophys. Res., 102, 23 50523 517, 1997.

Lowe, D., MacKenzie, A. R., Nikiforakis, N., and Kettleborough, J.: A condensed-mass advection based model for the simulation of liquid polar stratospheric clouds, Atmos. Chem. Phys., 3, 2938, 2003, http://www.atmos-chem-phys.net/3/29/2003/.

Luo, B., Carslaw, K. S., Peter, T., and Clegg, S. L.: Vapour pressures of $\mathrm{H}_{2} \mathrm{SO}_{4} / \mathrm{HNO}_{3} / \mathrm{HCl} / \mathrm{HBr} / \mathrm{H}_{2} \mathrm{O}$ solutions to low stratospheric temperatures, Geophys. Res. Let., 22, 247-250, 1995.

Luo, B., Krieger, U. K., and Peter, T.: Densities and refractive indices of $\mathrm{H}_{2} \mathrm{SO}_{4} / \mathrm{HNO}_{3} / \mathrm{H}_{2} \mathrm{O}$ solutions, Geophys. Res. Lett., 23, 3707-3710, 1996.

Lutman, E. R., Pyle, J. A., Jones, R. L., Lary, D. L., MacKenzie, A. R., Kilbane-Dawe, I., Larsen, N., and Knudsen, B.: Trajectory model studies of $\mathrm{ClO}_{\mathrm{x}}$ activation during the 1991/92 northern hemispheric winter, Geophys. Res. Lett., 21, 1419-1422, 1994.

Mann, G. W., Davies, S., Carslaw, K. S., and Chipperfield, M. P.: Factors controlling Artic denitrification in cold winters of the 1990s, Atmos. Chem. Phys., 3, 403-416, 2003, http://www.atmos-chem-phys.net/3/403/2003/.

Meilinger, S. K., Koop, T., Luo, B. P., Huthwelker, T., Carslaw, K. S., Krieger, U., Crutzen, P. J., and Peter, T.: Size-dependent Stratospheric Droplet Composition in lee wave Temperature Fluctuations and their potential role in PSC Freezing, Geophys. Res. Lett., 22, 3031-3034, 1995.

Molina, M. J., Zhang, R., Wooldridge, P. J., McMahon, J. R., Kim, J. E., Chang, H. Y., and Beyer, K. D.: Physical Chemistry of the $\mathrm{H}_{2} \mathrm{SO}_{4} / \mathrm{HNO}_{3} / \mathrm{H}_{2} \mathrm{O}$ System: Implications for Polar Stratopsheric Clouds, Science, 261, 1418-1423, 1993.

Northway, M. J., Gao, R. S., Popp, P. J., Holecek, J. C., Fahey, D. W., Carslaw, K. S., Tolbert, M. A., Lait, L. R., Dhaniyala, S., Flagan, R. C., Wennberg, P. O., Mahoney, M. J., Herman, R. L., Toon, G. C., and Bui, T. P.: An analysis of large $\mathrm{HNO}_{3}-$ containing particles sampled in the Arctic stratosphere during the winter of 1999/2000, J. Geophys. Res., 107(D20), 8298, doi:10.1029/2001JD001079, 2002.

Pilinis, C.: Derivation and Numerical Solution of the Species Mass Distribution Equations for Multicomponent Particulate Systems, Atmos. Environ., 24A, 1923-1928, 1990.

Sander, S. P., Friedl, R. R., Ravishankara, A. R., Golden, D. M., Kolb, C. E., Kurylo, M. J., Huie, R. E., Orkin, V. L., Molina, M. J., Moortgat, G. K., and Finlayson-Pitts, B. J.: Chemical Kinetics and Photochemical Data for Use in Atmospheric Studies, Evaluation number 14, JPL Publication 02-25, Pasadena, 2003.

Schauffler, S. M., Atlas, E. L., Donnelly, S. G., Andrews, A., Montzka, S. A., Elkins, J. W., Hurst, D. F., Romashkin, P. A., Dutton, G. S., and Stroud, V.: Chlorine budget and partitioning during the Stratospheric Aerosol and Gas Experiment (SAGE) III Ozone Loss and Validation Experiment (SOLVE), J. Geophys. Res., 108(D5), 4173, doi:10.1029/2001JD002040, 2003.

Schmitt, J.: Aufbau und Erprobung eines in-situ-Mess-Systems am Höhenforschungsflugzeug M55-Geophysica, PhD thesis, ISSN 1434-8454, ISRN DLR-FB-2003-21, 2003.

Schreiner, J., Voigt, C., Kohlmann, A., Arnold, F., Mauersberger, K., and Larsen, N.: Chemical Analysis of Polar Stratospheric Cloud Particles, Science, 283, 968-970, 1999.

Sessler, J., Good, P., MacKenzie, A. R., and Pyle, J. A.: What role do type I polar stratospheric cloud and aerosol parameterizations play in modelled lower stratospheric chlorine activation and ozone loss?, J. Geophys. Res., 101, 28 817-28 835, 1996.

Shi, Q., Jayne, J. T., Kolb, C. E., Worsnop, D. R., and Davidovits, P.: Kinetic model for reaction of $\mathrm{ClONO}_{2}$ with $\mathrm{H}_{2} \mathrm{O}$ and $\mathrm{HCl}$ and $\mathrm{HOCl}$ with $\mathrm{HCl}$ in sulfuric acid solutions, J. Geophys. Res., 106, 24 259-24274, 2001.

Stefanutti, L., MacKenzie, A. R., Santacesaria, V., Adriani, A., Balestri, S., Borrmann, S., Khattatov, V., Mazzinghi, P., Mitev, V., Rudakov, V., Schiller, C., Toci, G., Volk, C. M., Yushkov, V., Flentje, H., Kiemle, C., Redaelli, G., Carslaw, K. S., Noone, K., and Peter, T.: The APE-THESEO Tropical Campaign: An Overview, J. Atmos. Chem., 48, 1-33, 2004.

Tabazadeh, A., Turco, R. P., and Jacobson, M. Z.: A model for studying the composition and chemical effects of stratospheric clouds, J. Geophys. Res., 99, 12 897-12 914, 1994.

Tabazadeh, A., Turco, R. P., Drdla, K., and Jacobson, M. Z.: A study of type 1 polar stratospheric cloud formation, Geophys. Res. Lett., 21, 1619-1622, 1994.

Tabazadeh, A., Toon, O. B., Gary, B. L., Bacmeister, J. T., and Schoeberl, M. R.: Observational constraints on the formation of Type 1a polar stratospheric clouds, Geophys. Res. Lett., 23, 2109-2112, 1996.

Toon, O. B., Browell, E. V., Kinne, S., and Jordan, J.: An analysis of lidar observations of polar stratospheric clouds, Geophys. Res. Lett., 17, 393-396, 1990.

Toon, O. B., and Tolbert, M.: Spectroscopic evidence against nitric acid trihydrate in polar stratospheric clouds, Nature, 375, 218221, 1995.

Voigt, C., Schreiner, J., Kohlmann, A., Zink, P., Mauersberger, K., Larsen, N., Deshler, T., Kröger, C., Rosen, J., Adriani, A., Cairo, F., Donfrancesco, G. D., Viterbini, M., Ovarlez, J., Ovarlez, H., David, C., and Dörnbrack, A.: Nitric Acid Trihydrate (NAT) in Polar Stratospheric Clouds, Science, 290, 1756-1758, 2000a.

Voigt, C., Tsias, A., Dörnbrack, A., Meilinger, S., Luo, B., Schreiner, J., Larsen, N., Mauersberger, K., and Peter, T.: Nonequilibrium compositions of liquid polar stratospheric clouds in gravity waves, Geophys. Res. Lett., 27, 3873-3876, 2000 b.

Voigt, C., Larsen, N., Deshler, T., Kröger, C., Schreiner, J., Mauersberger, K., Luo, B., Adriani, A., Cairo, F., Donfrancesco, G. D., Ovarlez, J., Dörnbrack, A., Knudsen, B., and Rosen, J.: In situ mountain-wave polar stratospheric cloud measurements: Implications for nitric acid trihydrate formation, J. Geophys. Res., 108(D5), 8331, doi:10.1029/2001JD001185, 2003.

Voigt, C., Schlager, H., Luo, B. P., Dörnbrack, A., Roiger, A., Stock, P., Curtius, J., Vössing, H., Borrmann, S., Davies, S., Konopka, P., Schiller, C., Shur, G., and Peter, T.: Nitric acid trihydrate (NAT) formation at low NAT supersaturations, Atmos. Chem. Phys., 5, 1371-1380, 2005, 
http://www.atmos-chem-phys.net/5/1371/2005/.

von Hobe, M., Grooß, J.-U., Müller, R., and Stroh, F.: A Reevaluation of the $\mathrm{ClO} / \mathrm{ClO}$ Dimer Equilibrium Constant based on In-Situ Observations, Atmos. Chem. Phys., 5, 693-702, 2005, http://www.atmos-chem-phys.net/5/693/2005/.

Weisser, C., Mauersberger, K., Schreiner, J., Larsen, N., Cairo, F., Adriani, A., Ovarlez, J., and Deshler, T.: Composition analysis of liquid particles in the Arctic stratopshere, Atmos. Chem. Phys., 6, 689-696, 2006,

http://www.atmos-chem-phys.net/6/689/2006/.

Wernli, H. and Davis, H. C.: A Lagrangian-based analysis of extratropical cyclones. 1. The method and some applications, Q. J. Roy. Meteorol. Soc., 123, 467-489, 1997.

Wirth, M., Tsias, A., Dörnbrack, A., Weiss, V., Carslaw, K. S., Leutbecher, M., Renger, W., Volkert, H., and Peter, T.: Model-guided Lagrangian observation and simulation of mountain polar stratospheric clouds, J. Geophys. Res., 104, 23 971-23 981, 1999.
WMO: Scientific Assessment of Ozone Depletion: 2002, Report 47, Global Ozone Research and Monitoring Project, Geneva, 2003.

Worsnop, D. R., Fox, L. E., Zahniser, M. S., and Wofsy, S. C.: Vapor-Pressures of Solid Hydrates of Nitric-Acid - Implications for Polar Stratospheric Clouds, Science, 259, 71-74, 1993.

Zhang, R., Wooldridge, P. J., and Molina, M. J.: Vapor Pressure Measurements for the $\mathrm{H}_{2} \mathrm{SO}_{4} / \mathrm{HNO}_{3} / \mathrm{H}_{2} \mathrm{O}$ and $\mathrm{H}_{2} \mathrm{SO}_{4} / \mathrm{HCl} / \mathrm{H}_{2} \mathrm{O}$ Systems: Incorporation of Stratospheric Acids into Background Sulfate Aerosols, J. Phys. Chem., 97, 8541-8548, 1993.

Zöger, M., Afchine, A., Eicke, N., Gerhards, M. T., Klein, E., McKenna, D. S., Morschel, U., Schmidt, U., Tan, V., Tuitjer, F., Woyke, T., and Schiller, C.: Fast in situ stratospheric hygrometers: A new family of balloon-borne and airborne Lyman a photofragment fluorescence hygrometers, J. Geophys. Res., 104, 1807-1816, 1999. 